\title{
SURFACE COMPLEXATION MODELING IN VARIABLE CHARGE SOILS: CHARGE CHARACTERIZATION BY POTENTIOMETRIC TITRATION
}

\author{
Giuliano Marchi $^{(1)^{*}}$, Cesar Crispim Vilar ${ }^{(2)}$, George O’Connor ${ }^{(3)}$ and Marx Leandro \\ Naves Silva ${ }^{(4)}$
}

(1) Empresa Brasileira de Pesquisa Agropecuária, Embrapa Cerrados, Brasília, Distrito Federal, Brasil.

(2) Universidade do Estado de Mato Grosso, Campus Nova Xavantina, Nova Xavantina, Mato Grosso, Brasil.

(3) University of Florida, Soil and Water Sciences Department, Gainesville, Florida, United States.

(4) Universidade Federal de Lavras, Departamento de Ciência do Solo, Lavras, Minas Gerais, Brasil.

* Corresponding author.

E-mail: giuliano.marchi@embrapa.br

\begin{abstract}
Intrinsic equilibrium constants of 17 representative Brazilian Oxisols were estimated from potentiometric titration measuring the adsorption of $\mathrm{H}^{+}$and $\mathrm{OH}^{-}$on amphoteric surfaces in suspensions of varying ionic strength. Equilibrium constants were fitted to two surface complexation models: diffuse layer and constant capacitance. The former was fitted by calculating total site concentration from curve fitting estimates and pH-extrapolation of the intrinsic equilibrium constants to the PZNPC (hand calculation), considering one and two reactive sites, and by the FITEQL software. The latter was fitted only by FITEQL, with one reactive site. Soil chemical and physical properties were correlated to the intrinsic equilibrium constants. Both surface complexation models satisfactorily fit our experimental data, but for results at low ionic strength, optimization did not converge in FITEQL. Data were incorporated in Visual MINTEQ and they provide a modeling system that can predict protonation-dissociation reactions in the soil surface under changing environmental conditions.
\end{abstract}

Keywords: intrinsic equilibrium constants, Oxisols, FITEQL, Visual MINTEQ, chemical equilibrium software. 


\title{
RESUMO: MODELAGEM POR COMPLEXAÇÃO DE SUPERFÍCIE EM SOLOS DE CARGA VARIÁVEL: CARACTERIZAÇÃO DE CARGAS POR TITULAÇÃO POTENCIOMÉTRICA
}

\begin{abstract}
Constantes de equilíbrio intrínseco de 17 Latossolos brasileiros representativos foram estimadas a partir de titulações potenciométricas, medindo-se a adsorção de $\mathrm{H}^{+}$e $\mathrm{OH}^{-}$nas superfícies anfotéricas de suspensões com força iônica variada. As constantes de equilíbrio foram ajustadas a dois modelos de complexação: camada difusa e capacitância constante. O primeiro modelo foi ajustado pelo cálculo da concentração total de sítios a partir de estimativas de ajustes e extrapolação do valor de $p H$ das constantes de equilíbrio intrínsecas ao PCLPZ (cálculo manual), considerando um ou dois sítios reativos, e também pelo programa FITEQL. O segundo modelo foi ajustado somente pelo FITEQL com um sítio reativo. Os atributos químicos e físicos do solo foram correlacionados às constantes de equilíbrio intrínsecas. Os dois modelos de complexação de superfícies se ajustaram satisfatoriamente aos dados experimentais, mas para resultados em baixa força iônica a otimização não convergiu no FITEQL. Os dados foram incorporados no Visual MINTEQ e fornecem um sistema de modelagem que pode predizer reações de protonação-dissociação na superfície do solo sob diversas condições ambientais.
\end{abstract}

Palavras-chave: constantes de equilíbrio intrínsecas, Latossolos, FITEQL, Visual MINTEQ, programa de equilíbrio químico.

\section{INTRODUCTION}

The destination of metals and organic and inorganic substances in the environment is strongly dependent on soil pH (Jonsson, 2007; Davis, 2008). Simulations of $\mathrm{H}^{+}$and $\mathrm{OH}^{-}$adsorption in soil particles through intrinsic equilibrium constants $\left(\log K_{a}^{\text {int }}\right)$ in geochemical speciation models are an important step toward defining movement of substances in the soil profile.

Surface interactions involving simple minerals, as well as synthesized single metal oxide and hydroxide minerals, were described using surface complexation models (SCMs). These models are similar in their descriptions of surface reactions, each treating the surface as if it were composed of amphoteric hydroxide functional groups capable of reacting with sorbing cationic or anionic species to form surface complexes. The models differ in complexity, their descriptions of the electrical diffuse layer, and how changes in the background electrolyte concentration are incorporated in model computations (Kriaa et al., 2009). Among SCMs, the double layer model (DLM) and the constant capacitance model (CCM) were applied to model the experimental results of oxide surfaces (Stumm et al., 1980; Dzombak and Morel, 1990). Application of SCMs to soils is less common than to pure minerals because of the complex chemical composition of soils (Kriaa et al., 2009). Intrinsic surface protonation-dissociation parameters for surface complexation modeling in soils are often adopted from calculations on compilations of reference hydrous oxide minerals (Charlet and Sposito, 1987). However, models that are based on oxide systems often give unsatisfactory results when applied to the measurement of surface charge chemistry of soils (Duquette and Hendershot, 1993).

Although the surface charge behavior of Oxisols is dominated by inorganic hydroxyl groups lying at the particle surface that are similar to the surfaces of pure oxide systems (Duquette and Hendershot, 1993), $\log K_{a}^{\text {int }}$ values of protonation-dissociation constants for two Oxisols were found to be 2 to 4 log units smaller than typical values for $\mathrm{Al}$ and Fe hydrous oxides by Charlet and Sposito (1987). Smaller $\log K_{a}^{\text {int }}$ values for Oxisols reflect the effect of organic materials coating mineral surfaces that interferes in charge-dependent soil reactions (Marchi et al., 2006; Dobbss et al., 2008; Alleoni et al., 2009).

Surface complexation models ( $\mathrm{SCMs}$ ) are directly linked to the surface area of the materials under study, and $\log K_{a}^{\text {int }}$ values of Oxisols are strongly influenced by the effect of organic substances. In a study of more than 400 Oxisol profiles, Tognon et al. (1998) showed that increases in clay content increased soil organic matter content. Therefore, surface area in Oxisols is a covariant of soil organic matter.

$\log K_{a}^{\text {int }}$ values estimated from potentiometric titration data of soils may be used to define model parameters for use in DLM and CCM. Use of these parameters within the Visual MINTEQ may provide a modelling system that can predict protonation-dissociation reactions in the soil surface under changing environmental conditions.

The aim of this study was to estimate $\log K_{a}^{\text {int }}$ values from potentiometric titration data of 17 Oxisols from Brazil at three ionic strengths to define model parameters such as average site concentration 
for use in DLM (considering one or two surface reactive sites) and in CCM.

\section{MATERIAL AND METHODS}

Original titration data of soils from Silva et al. (1996) were used to estimate $\log K_{a}^{\text {int }}$ for 17 Oxisols (Tables 1 and 2). The authors used samples from the 0.00-0.20 m layer of Oxisols collected from several Brazilian regions, which were sieved through a $2 \mathrm{~mm}$ mesh. Further details and location of origin of each of these soils were published elsewhere (Silva et al., 1996; Pierangeli et al., 2001). This data was selected because these soils are representative Brazilian Oxisols; and as the soil is well characterized, including surface area data, it is among the few Brazilian published works that allow the present study to be performed. Soil titration was performed in triplicate with the use of $5 \mathrm{~g}$ of soil in $25 \mathrm{~mL} \mathrm{NaCl}$ solutions of 1.0, 0.1, and $0.001 \mathrm{~mol} \mathrm{~L}^{-1}$. The $\mathrm{pHs}$ of the suspensions were adjusted with $1 \mathrm{~mL}$ of $0.02 \mathrm{~mol} \mathrm{~L}^{-1} \mathrm{HCl}$ or $\mathrm{NaOH}$ and allowed to come to equilibrium for $72 \mathrm{~h}$ for each step in titration. The operation was repeated until the $\mathrm{pH}$ 's of the suspensions were near 3 with the addition of acid, or near 8 with the addition of base. A control sample of solution without soil was simulated using the chemical speciation software Visual MINTEQ (Gustafsson, 2014). The SIT equation (Sukhno and Buzko, 2004) was used for corrections in ion ic activity.

Two surface complexation models were considered: the diffuse layer model (DLM) (Dzombak and Morel, 1990), and the constant capacitance model (CCM) (Stumm et al., 1980). Parameters for the DLM were estimated by the following methodology.

The adsorption density of potential determining ions $\left(\mathrm{H}^{+}\right.$and $\left.\mathrm{OH}^{-}\right)$in the soil was calculated from the experimental data as follows (Equation 1):

$\Gamma_{\mathrm{H}}-\Gamma_{\mathrm{OH}}=\left(\frac{1}{A S}\right) \times\left(\mathrm{Ca}-\mathrm{Cb}-\left[\mathrm{H}^{+}\right]+\left[\mathrm{OH}^{-}\right]\right)$

Eq. 1

where $\Gamma_{\mathrm{H}}$ and $\Gamma_{\mathrm{OH}}$ are the net surface $\mathrm{H}^{+}$and $\mathrm{OH}^{-}$ adsorption densities $\left(\mathrm{mol} \mathrm{m}^{-2}\right)$, respectively; $A$ is the specific surface area $\left(\mathrm{m}^{2} \mathrm{~g}^{-1}\right) ; S$ is the solid to solution ratio $\left(\mathrm{g} \mathrm{L}^{-1}\right)$; $\mathrm{Cb}$ and $\mathrm{Ca}$ are the concentrations of base or acid, respectively, added per liter of solution $\left(\mathrm{mol} \mathrm{L}{ }^{-1}\right)$; and [ ] indicates concentration $\left(\mathrm{mol} \mathrm{L}^{-1}\right)$;

The net proton surface charge density, $\sigma_{\mathrm{H}}\left(\mathrm{C} \mathrm{m}^{-2}\right)$, was calculated (Equation 2):

$\sigma_{H}=\mathrm{F} \times\left(\Gamma_{\mathrm{H}}-\Gamma_{\mathrm{OH}}\right)$

Eq. 2

where $\mathrm{F}$ is the Faraday constant $\left(96485 \mathrm{C} \mathrm{mol}^{-1}\right)$.

Table 1. Soil characterization (chemical and mineralogical properties) from the 0.00-0.20 $\mathrm{m}$ layer of 17 Brazilian Oxisols

\begin{tabular}{|c|c|c|c|c|c|c|c|c|c|c|c|c|c|c|c|}
\hline \multirow{2}{*}{ Soil $^{(1)}$} & \multirow{2}{*}{$\begin{array}{c}\text { Location } \\
\text { Municipality, } \\
\text { State }\end{array}$} & \multicolumn{6}{|c|}{ Mineralogical } & \multicolumn{3}{|c|}{ Sulphuric dissolution } & \multicolumn{2}{|c|}{$\mathrm{Fe}_{2} \mathrm{O}_{3}$} & \multirow{2}{*}{$\mathbf{K i}$} & \multirow{2}{*}{$\mathbf{K r}$} & \multirow{2}{*}{$\mathbf{T}$} \\
\hline & & $\mathrm{Vm}-\mathrm{OH}^{(2)}$ & $\mathbf{K t}$ & Gb & Gt & $\mathrm{Hm}$ & Mh & $\mathrm{SiO}_{2}$ & $\mathrm{Al}_{2} \mathrm{O}_{3}$ & $\mathrm{Fe}_{2} \mathrm{O}_{3}$ & CBD & $\mathbf{O x}$ & & & \\
\hline & & \multicolumn{11}{|c|}{$\mathrm{g} \mathrm{kg}^{-1}$} & & & $\operatorname{mol}_{\mathrm{c}} \mathrm{kg}^{-1}$ \\
\hline 1 & Passo Fundo, RS & 26 & 254 & 95 & 6 & 89 & 0 & 149 & 143 & 63 & 38 & 2.8 & 1.8 & 1.2 & 181 \\
\hline 2 & Ponta Grossa, PR & 14 & 344 & 172 & 42 & 58 & 0 & 172 & 220 & 178 & 87 & 2.5 & 1.3 & 0.7 & 79 \\
\hline 3 & Londrina, PR & 75 & 420 & 225 & 11 & 122 & 8 & 253 & 270 & 268 & 119 & 6 & 1.6 & 0.8 & 104 \\
\hline 4 & Paranavaí, PR & 13 & 103 & 11 & 2 & 9 & 0 & 42 & 66 & 27 & 11 & 0.7 & 1.1 & 0.8 & 41 \\
\hline 5 & Campinas, SP & 13 & 312 & 180 & 34 & 61 & 0 & 161 & 208 & 178 & 78 & 3 & 1.3 & 0.7 & 86 \\
\hline 6 & Jaboticabal, SP & 9 & 171 & 141 & 3 & 15 & 0 & 114 & 192 & 100 & 51 & 2.1 & 1.0 & 0.7 & 66 \\
\hline 7 & Lavras, MG & 11 & 190 & 484 & 16 & 19 & 0 & 159 & 270 & 125 & 46 & 2.2 & 1.0 & 0.7 & 60 \\
\hline 8 & Lavras, MG & 19 & 305 & 374 & 22 & 0 & 0 & 141 & 330 & 110 & 60 & 0.3 & 0.7 & 0.5 & 64 \\
\hline 9 & Sete Lagoas, MG & 18 & 491 & 254 & 14 & 73 & 0 & 343 & 319 & 120 & 73 & 3.4 & 1.2 & 0.9 & 41 \\
\hline 10 & Goiânia, GO & 2 & 19 & 448 & 26 & 45 & 0 & 95 & 241 & 108 & 59 & 2.2 & 0.7 & 0.5 & 74 \\
\hline 11 & Planaltina, DF & 40 & 360 & 75 & 17 & 29 & 0 & 150 & 187 & 88 & 52 & 3.1 & 1.4 & 0.9 & 103 \\
\hline 12 & Areia, PB & 17 & 420 & 0 & 3 & 0 & 0 & 135 & 149 & 39 & 15 & 1.8 & 1.5 & 1.2 & 110 \\
\hline 13 & Ubajara, CE & 2 & 69 & 69 & 10 & 0 & 0 & 46 & 75 & 15 & 9 & 0.9 & 1.0 & 0.9 & 88 \\
\hline 14 & Tomé-Açú, PA & 27 & 327 & 0 & 6 & 0 & 0 & 124 & 135 & 33 & 10 & 0.7 & 1.6 & 1.2 & 88 \\
\hline 15 & Ijuí, RS & 66 & 421 & 58 & 10 & 107 & 8 & 199 & 182 & 210 & 80 & 3.7 & 1.9 & 0.9 & 148 \\
\hline 16 & Chapecó, SC & 121 & 526 & 61 & 4 & 71 & 7 & 246 & 217 & 139 & 62 & 4.7 & 1.9 & 1.2 & 158 \\
\hline 17 & Dourados, MS & 36 & 402 & 112 & 11 & 79 & 10 & 203 & 213 & 301 & 76 & 3.2 & 1.6 & 0.7 & 117 \\
\hline
\end{tabular}

(1) Data from Silva et al. (1996) and Pierangeli et al. (2001); ${ }^{(2)} \mathrm{Vm}-\mathrm{OH}$ : hydroxy-interlayered vermiculite; Kt: kaolinite; Gb: gibbsite; Gt: goethite; Hm: hematite; $\mathrm{Mh}$ : maghemite; $\mathrm{SiO}_{2}, \mathrm{Al}_{2} \mathrm{O}_{3}$, and $\mathrm{Fe}_{2} \mathrm{O}_{3}$ (Vettori, 1969; Embrapa, 1979); ki: molecular relationship $\mathrm{SiO}_{2} / \mathrm{Al}_{2} \mathrm{O}_{3}$; kr: molecular relationship $\mathrm{SiO}_{2} /\left(\mathrm{Al}_{2} \mathrm{O}_{3}+\mathrm{Fe}_{2} \mathrm{O}_{3}\right)$; CBD: $\mathrm{Fe}_{2} \mathrm{O}_{3}$ extracted by the citrate-bicarbonate-dithionite method (Mehra and Jackson, 1960); Ox: $\mathrm{Fe}_{2} \mathrm{O}_{3}$ extracted by ammonium oxalate (Schwertmann, 1964); T: cation exchange capacity at pH 7.0. 
Table 2. Soil granulometry, surface area $(A)$, and organic matter content $(O M)$ from the 0.00-0.20 m layer of 17 Brazilian Oxisols

\begin{tabular}{|c|c|c|c|c|}
\hline Soil $^{(1)}$ & Clay & Sand & $A$ & $\mathrm{OM}$ \\
\hline & \multicolumn{2}{|c|}{$\mathrm{g} \mathrm{kg}^{-1}$} & $\mathrm{~m}^{2} \mathrm{~g}^{-1}$ & $\mathrm{~g} \mathrm{~kg}^{-1}$ \\
\hline 1 & 470 & 470 & 139.7 & 31 \\
\hline 2 & 630 & 290 & 166.1 & 22 \\
\hline 3 & 860 & 60 & 182.3 & 14 \\
\hline 4 & 139 & 860 & 90.4 & 9 \\
\hline 5 & 600 & 300 & 166.6 & 26 \\
\hline 6 & 339 & 660 & 147.0 & 29 \\
\hline 7 & 720 & 180 & 156.1 & 33 \\
\hline 8 & 720 & 170 & 182.6 & 48 \\
\hline 9 & 850 & 120 & 171.6 & 38 \\
\hline 10 & 540 & 360 & 145.3 & 30 \\
\hline 11 & 520 & 370 & 159.8 & 41 \\
\hline 12 & 440 & 550 & 162.9 & 43 \\
\hline 13 & 150 & 800 & 91.0 & 26 \\
\hline 14 & 360 & 600 & 103.1 & 16 \\
\hline 15 & 670 & 170 & 187.6 & 26 \\
\hline 16 & 790 & 60 & 196.6 & 45 \\
\hline 17 & 279 & 240 & 169.9 & 13 \\
\hline
\end{tabular}

(1) Data from Silva et al. (1996) and Pierangeli et al. (2001); A: soil specific surface area (Carter et al., 1965); OM: soil organic matter (Embrapa, 1979).

Similarly, surface charge, Q (mol kg-1), can be written as (Equation 3):

$Q=\frac{\left(\sigma_{H} \times A\right)}{F}$

Eq. 3

The mass balance on the total number of adsorption sites is assumed as imposed via equation 4:

$\mathrm{SOH}^{0}=\mathrm{SOH}-\mathrm{SO}^{-}-\mathrm{SOH}_{2}^{+}$

Eq. 4

where $\mathrm{S}$ denotes a structural metal ion of the oxide surface; $\mathrm{SOH}_{2}^{+}, \mathrm{SOH}^{0}$, and $\mathrm{SO}^{-}$are the protonated, neutral, and deprotonated surface species, respectively; and surface plane protons are depicted by $\mathrm{H}^{+}$.

A curve fitting hydrogen ion sorption was adapted from Duquette and Hendershot (1993), where the maximum charge developed from one site $\left(\mathrm{Q}_{\mathrm{m}}=\mathrm{SO}^{-}+\mathrm{SOH}\right)$ can be integrated in an equation, such as the Multi-Langmuir. Whereas these authors used the approach for back titration, the approach can be used to estimate the maximum charge for an acid-base titration as $\mathrm{Q}_{\mathrm{m}}=\mathrm{B}_{\max }=\mathrm{SOH}_{2}^{+}+\mathrm{SOH}$, by plotting $\mathrm{Q}+1\left(\mathrm{~mol} \mathrm{~kg}^{-1}\right)$ vs $\left[\mathrm{H}^{+}\right]\left(\mathrm{mol} \mathrm{L}^{-1}\right)($ Equation 5):

$(Q+1)=\left(\frac{\mathrm{B}_{\max 1} \times\left[H^{+}\right]}{K d_{1}+\left[H^{+}\right]}\right)+\left(\frac{\mathrm{B}_{\max 2} \times\left[H^{+}\right]}{K d_{2}+\left[H^{+}\right]}\right)$

Eq. 5

where $B_{\max 1}$ and $B_{\max 2}$ are related to the maximum charges of two adsorption sites in soils. Total site concentration $\left(\mathrm{Nt} ; \mathrm{mol} \mathrm{kg}^{-1}\right)$ was estimated by $\mathrm{Nt}=\left[\left(\mathrm{B}_{\max 1}+\mathrm{B}_{\max 2}\right)-1 / 1000\right]$. Total site concentrations $\left(\mathrm{mmol} \mathrm{kg}^{-1}\right)$ for two sites in soils were estimated by $\mathrm{Nt}_{1}=\left[\left(\mathrm{Bmax}_{1} \times \mathrm{Nt}\right) /\left(\mathrm{Bmax}_{1}+\mathrm{Bmax}_{2}\right)\right]$, and $\mathrm{Nt}_{2}=\left[\left(\mathrm{Bmax}_{2} \times \mathrm{Nt}\right) /\left(\mathrm{Bmax}_{1}+\mathrm{Bmax}_{2}\right)\right]$. Maximum charge parameters were obtained adjusting data to equation 5 by the least sum of squares from residuals, using the Sigma Plot 12.0 software.

The acid/base properties of an amphoteric oxide surface are described by two reactions (Charlet and Sposito, 1987) (Equations 6 and 7):

$K_{a 1}=\frac{\{S O H\} \times\left[H^{+}\right]_{\sigma_{H} \rightarrow 0}}{\left\{S O H_{2}^{+}\right\}} K a_{1}^{i n t}$

$K_{a 2}=\frac{\left|\left\{S O^{-}\right\} \times\left[H^{+}\right]\right|_{\sigma_{H} \rightarrow 0}}{\{S O H\}} K a_{2}^{i n t}$

where \{\} denotes the concentration of surface species $\left(\mathrm{mol} \mathrm{kg}^{-1}\right)$.

Microscopic acidity constants where then calculated from conditional equilibrium constants. Intrinsic equilibrium constants were estimated by the graphical method (Stumm and Morgan, 1996).

The software FITEQL 4.0 (Herbelin and Westall, 1999) was used to estimate intrinsic constants for the CCM. As the CCM is very insensitive to values of capacitance density $\left(\mathrm{C}_{1}\right)$ (Goldberg, 1995), and the choice of this value is arbitrary (Hayes et al., 1991); Hayes et al. (1991) recommended using the best fit values $\left(\sim 1.0 \mathrm{~F} \mathrm{~m}^{-2}\right)$. We chose to use a $\mathrm{C}_{1}$ value of $1.06 \mathrm{~F} \mathrm{~m}^{2}$ (derived from $\mathrm{Al}$ oxides) (Westall and Hohl, 1980).

Intrinsic equilibrium constants passed through Dixon's outlier and normality (Shapiro-Wilk and Lilliefors) tests using PROUCL software (Maichle and Singh, 2013). Intrinsic equilibrium constants were correlated linearly (Pearson's r) with soil properties, as shown in Silva et al. (1996), and Pierangeli et al. (2001).

\section{RESULTS AND DISCUSSION}

Values of experimental charge density of soils estimated from titration at various ionic strengths (Figure 1) were used to estimate values of surface charge (Figure 2). At a given ionic strength, surface charge density decreased with increasing $\mathrm{pH}$ for all soils studied. The highest values of surface charge density were measured at low $\mathrm{pH}$ for all soils. An Oxisol from Paranavaí, PR, there was a convergence at the point of zero salt effect (PZSE) for all three curves (Figure 1). Convergence at the PZSE did not happen to all 17 soils, and was also observed in another study (Chorover and Sposito, 1995). 


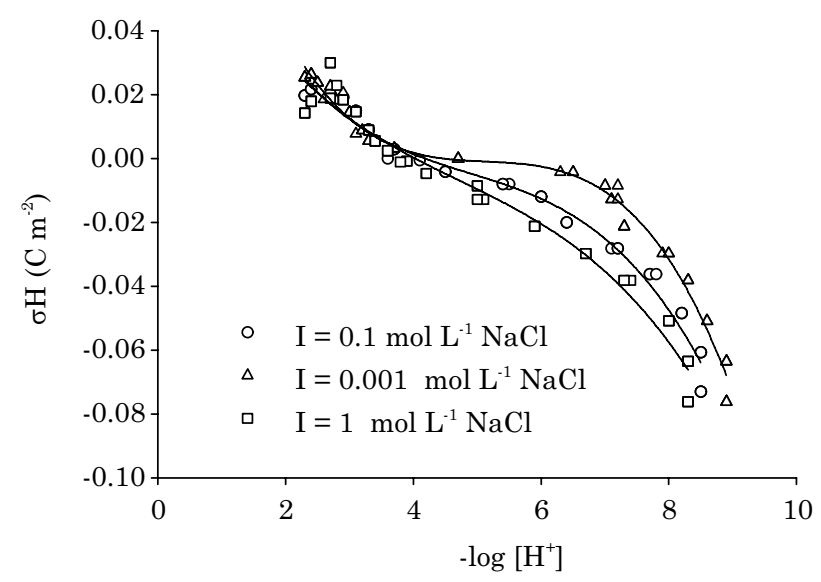

Figure 1. Experimental surface charge density $\sigma_{H}$ versus $\mathrm{pH}$ for an Oxisol from Paranavaí, PR, Brazil, at three ionic strengths.

Estimates of total site concentration (Nt; Figure 2) rendered coefficients of determination $\left(\mathrm{R}^{2}\right)$ ranging from 0.94 to 0.99 for all soils and ionic strengths. Inner-sphere surface complex charge is negligible in Oxisols (Charlet and Sposito, 1987) and $\mathrm{H}^{+}$and $\mathrm{OH}^{-}$ react with multiple soil surface functional groups, i.e., organic and inorganic surface functional groups from different minerals (Duquette and Hendershot, 1993). Thus, data transformation allowed fitting data below the point of zero net charge (PZNC), where positive and negative charges coexist.

In contrast with total surface charge estimated by hand calculation, results from titration data optimized in surface complexation models by FITEQL reveal that the weighted sum of squares of the residuals/degrees of freedom (WSOS/DF), a quality-of-fit parameter calculated from titration of soils, exceeded the limit recommended for pure minerals. It is assumed that the smaller value of WSOS/DF renders the best fit estimates. In general, values below 20 (for pure minerals) are considered as good fits (Herbelin and Westall, 1999). Given the differences between soils and pure minerals, as presented by Duquette and Hendershot (1993), soils are expected to exhibit greater variability and increased WSOS/DF values. Studying a Tunisian glauconite complex natural clay mineral, Kriaa et al. (2009) considered WSOS/DF values above 300 as unsatisfactory. For the calculations performed using FITEQL in our experimental data, average WSOS/DF values were above 300 (Table 3).

Values of $\mathrm{Nt}$ were set to be optimized through FITEQL, but some of the titration data of soils did not converge. As $\mathrm{Nt}$ values increase, convergence of the FITEQL program becomes more difficult, and overflow and singularity are two types of convergence problems (Goldberg, 1991). FITEQL optimized data of average site concentration for DLM and CCM (1 mol L'-1 $\mathrm{NaCl})$, and, for CCM

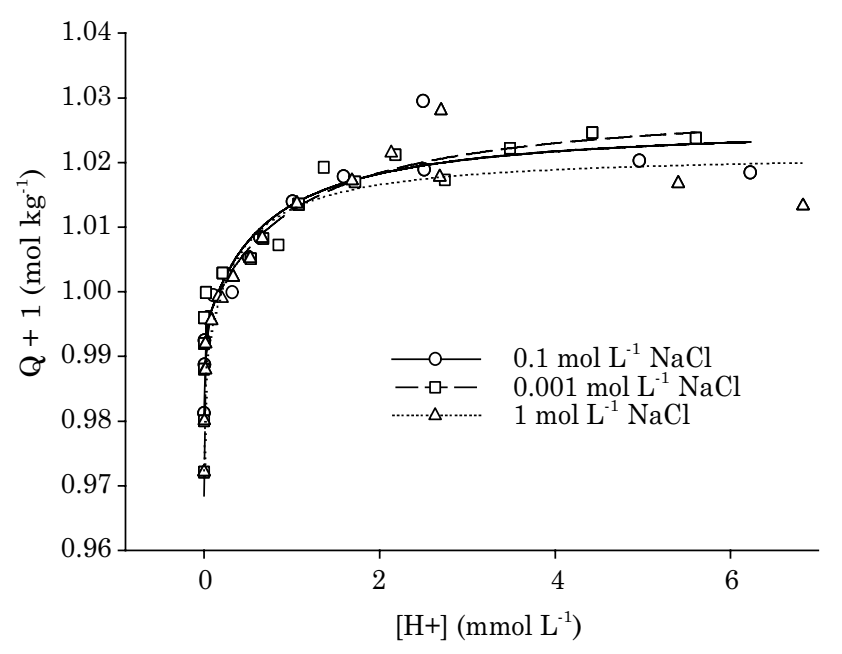

Figure 2. Surface charge $Q$ plus 1 versus $\left[\mathrm{H}^{+}\right]$for an Oxisol from Paranavaí, PR, Brazil.

$\left(0.1 \mathrm{~mol} \mathrm{~L}^{-1} \mathrm{NaCl}\right)$, this value was close to the value estimated by hand calculation (Excel spreadsheet; table 3) and was more consistent (lower standard deviation) among soils than values from hand calculation. The interfacial potential in the CCM [equation details described in Goldberg (1992)] does not depend on ionic strength, and the CCM surface equilibrium constants cannot be corrected for changing ionic strength conditions. Because of that, a different set of CCM surface constants is required for each set of ionic strength conditions to be modeled (Kriaa et al., 2009).

Site density $(\mathrm{Ns})$ or concentration $(\mathrm{Nt})$ is a sensitive and important parameter for both models (Hayes, et al., 1991), and, in speciation programs, is directly related to surface area and charge density or concentration of the material under study. Some publications (Goldberg et al., 2002; Goldberg, 2004; Goldberg et al., 2005) show a standard value for Ns used for soils of 2.31 sites $\mathrm{nm}^{-2}$ (information to convert $\mathrm{Ns}$ values to $\mathrm{Nt}$ is included in table 3 ). This Ns value was recommended for natural materials by Davis and Kent (1990). The value proposed by these authors may be subject to optimization from FITEQL.

For an Oxisol from Brazil, Charlet and Sposito (1987) found an Ntvalue of $144 \pm 45\left(\mathrm{I}=0.5 \mathrm{~mol} \mathrm{~L}^{-1} \mathrm{NaCl}\right.$; 1:1 background electrolyte suspensions). This value was used in equations such as 6 and 7 to estimate intrinsic surface equilibrium constants. These authors estimated $\log K_{a 1}^{i n t}$ and $\log K_{a 2}^{i n t}$ values of 2.33 and -6.34 in $9 \mathrm{mmol} \mathrm{L}^{-1} \mathrm{NaCl}$, and 2.07 and -5.97 in $3.6 \mathrm{mmol} \mathrm{L}^{-1} \mathrm{KNO}_{3}$, respectively. These values were very similar to those shown in tables 3,4 , and 5 . Charlet and Sposito (1987) also noted that values were 2 to 4 log units smaller than typical values for $\mathrm{Al}$ and $\mathrm{Fe}$ hydrous oxides, and that the difference reflects stronger surface acidity of the Oxisol relative to the metal oxides. 
Table 3. Site concentration (Nt) from 17 Brazilian Oxisols using the diffuse layer model (DLM), estimated by hand calculation in Excel spreadsheets, and by using the constant capacitance model (CCM), estimated by FITEQL 4.0

\begin{tabular}{|c|c|c|c|c|c|c|c|}
\hline & \multicolumn{5}{|c|}{ DLM } & \multicolumn{2}{|c|}{ CCM } \\
\hline & \multicolumn{3}{|c|}{ Excel spreadsheet } & \multirow[b]{3}{*}{ Nt } & \multirow{2}{*}{\multicolumn{2}{|c|}{ FITEQL $^{(1)}$}} & \multirow[b]{3}{*}{ WSOS/DF ${ }^{(2)}$} \\
\hline & \multirow{2}{*}{$\begin{array}{c}\text { One site } \\
\mathrm{Nt}\end{array}$} & \multicolumn{2}{|c|}{ Two sites } & & & & \\
\hline & & $\mathrm{Nt}_{1}$ & $\mathrm{Nt}_{2}$ & & WSOS/DF ${ }^{(2)}$ & $\mathrm{Nt}$ & \\
\hline & \multicolumn{4}{|c|}{$\mathrm{mmol} \mathrm{kg-1}$} & \multicolumn{3}{|c|}{$\mathrm{mmol} \mathrm{kg}{ }^{-1}$} \\
\hline & \multicolumn{5}{|c|}{$0.001 \mathrm{~mol} \mathrm{~L}^{-1} \mathrm{NaCl}$} & & \\
\hline Average & 92.9 & 84.4 & 11.8 & $\mathrm{NC}^{(3)}$ & $\mathrm{NC}$ & $\mathrm{NC}$ & $\mathrm{NC}$ \\
\hline $\mathrm{SD}^{(4)}$ & 18.9 & 15.9 & 10.2 & - & - & - & - \\
\hline \multicolumn{8}{|c|}{$0.1 \mathrm{~mol} \mathrm{~L}^{-1} \mathrm{NaCl}$} \\
\hline Average & 109.9 & 96.5 & 17.0 & $\mathrm{NC}$ & $\mathrm{NC}$ & 113.7 & 589 \\
\hline $\mathrm{SD}$ & 39.1 & 31.1 & 15.4 & - & - & 22.4 & 152 \\
\hline \multicolumn{8}{|c|}{$1 \mathrm{~mol} \mathrm{~L}^{-1} \mathrm{NaCl}$} \\
\hline Average & 150.6 & 124.4 & 26.2 & 89.1 & 762 & 91.7 & 758 \\
\hline $\mathrm{SD}$ & 83.5 & 60.3 & 23.9 & 13.1 & 141 & 27.6 & 155 \\
\hline
\end{tabular}

(1) Capacitance of inner Helmholtz layer $=1.06 \mathrm{~F} \mathrm{~m}^{-2} ;{ }^{(2)} \mathrm{SOS}$ is the weighted sum of squares of the residuals and DF is the degrees of freedom; ${ }^{(3)} \mathrm{NC}=$ No convergence; Site concentration $\left(\mathrm{Nt} ; \mathrm{mol} \mathrm{L}^{-1}\right)$ may be converted to site density $\left(\mathrm{Ns} ;\right.$ sites $\left.\mathrm{nm}^{-2}\right)$ by the following expression: $\mathrm{Nt}=\left(\mathrm{SA} \times \mathrm{Ns} \times \mathrm{CS} \times 10^{18}\right) / \mathrm{NA}$, where $\mathrm{SA}$ is the surface area $\left(\mathrm{m}^{2} \mathrm{~g}^{-1}\right), \mathrm{CS}$ is $\mathrm{g} \mathrm{L} \mathrm{L}^{-1}$, and NA is Avogadro's number; (4) SD: standard deviation.

The use of model parameters derived from average pure oxide materials such as $\log K_{a 1}^{\text {int }}=7.35$, and $\log K_{a 2}^{i n t}=-8.95$ (Goldberg and Sposito, 1984a,b) for Oxisol speciation would lead to a shift to the right (Figure 3) for dominant species, and the net surface charge would be positive for $\mathrm{pH}$ values from 4.5 to 6.5 (pH range of crop soils), which is not realistic. Therefore, modeling soils with initial inputs derived from oxide materials requires refitting and corrections for model geometry that may be optimized by FITEQL (Goldberg et al., 1996; Goldberg, 1999, 2000; Miller, 2001).

Surface charge and organic matter concentrations in surface horizons of Oxisols are closely related, and organic matter causes the point of zero salt effect (PZSE) to decrease (Dobbss et al., 2008). The authors suggest that mineral surfaces may be coated by organic matter that changes surface charge behavior. After the authors removed organic matter by $0.1 \mathrm{~mol} \mathrm{~L}^{-1} \mathrm{NaOH}$ from two Oxisols with clay mineralogy dominated by $\mathrm{Fe}$ and $\mathrm{Al}$ oxides, the PZSE shifted from 4.0 - 5.0 to 9.3 - 9.5, and, from two Oxisols with clay mineralogy dominated by kaolinite, from 4.1 to 5.7. Organic matter, therefore, has a big impact on the soil surface charge of Oxisols and may account for more than $50 \%$ of the total charge for these highly weathered soils (Alleoni et al., 2009). For SCM, in which results from further speciation are very strongly bound to soil surface area, and organic matter effects are not directly represented, a great variation in $\log K_{a}^{\text {int }}$ values among soils would render the modeling nearly impossible. However, $\log K_{a}^{\text {int }}$ variability for this group of soils was very small, probably because, for Brazilian Oxisols, organic matter and clay content are very closely related, and so is surface area (Tognon et al., 1998).

Of the 17 soils in the present study, two soils exhibited $\log K_{a}^{\text {int }}$ values that were considered outliers by Dixon's outlier test. One of them, a soil from Lavras, MG (soil no. 10), exhibited average $\log K_{a 1}^{i n t}=8.30 \pm 0.29$, and another, a soil from Londrina, PR, $\log K_{a 2}^{i n t}=-0.49 \pm 0.76$. These two soils will not be well represented by the present modeling, and there is no evidence from soil properties (Tables 1 and 2) that supports a difference in their $\log K_{a}^{\text {int }}$ values from other soils studied.

As the ionic strength of the data sets increased, the optimized values of intrinsic equilibrium constants decreased (Table 4). For the DLM, in $1 \mathrm{~mol} \mathrm{~L}^{-1} \mathrm{NaCl}$, hand calculation results (Table 4) were very close to those estimated by FITEQL (Table 5). Correlation of $\log K_{a}^{\text {int }}$, considering only one site, and soil properties from tables 1 and 2 showed that total $\mathrm{Fe}_{2} \mathrm{O}_{3}$ was positively and consistently (in all, or at least two studied ionic strengths) correlated with $\log K_{a 2}^{\text {int }}$ for DLM $(p<0.1)$. Surface area and kaolinite content correlated positively with $\log K_{a 1}^{\text {int }}$ for DLM $(\mathrm{p}<0.05)$, except for $1 \mathrm{~mol} \mathrm{~L}^{-1} \mathrm{NaCl}$.

When two sites were considered, $\log K_{a}^{\text {int }}$ from site A, for the 17 soils, correlated negatively with organic matter $(\mathrm{p}<0.1)$; and $\log K_{a 2}^{\text {int }}$ correlated positively with total $\mathrm{Fe}_{2} \mathrm{O}_{3}(\mathrm{p}<0.1)$. Even though the $\log K_{a}^{\text {int }}$ for all soils in site A did not exhibit normal distribution, its standard deviation was higher than the other average $\log K_{a}^{\text {int }}$ values, and soils could not be accurately represented in the model. These results could clearly 
be divided into two groups of soils. For the first group (soils 3, 10, 14 and 17; tables 1 and 2), $\log K_{a}^{\text {int }}$ values for site A of four soils could be recalculated as: 5.71 \pm 0.5 and $-4.83 \pm 0.39,5.40 \pm 0.38$ and $-3.54 \pm 0.49$, and $5.11 \pm 0.34$ and $-3.17 \pm 0.28$ for $0.001,0.1$, and 1 mol L ${ }^{-1} \mathrm{NaCl}$, respectively. $\log K_{a 2}^{i n t}$ from this group of soils correlated positively with total $\mathrm{Al}_{2} \mathrm{O}_{3}(p<0.1)$ for 0.1 , and $1 \mathrm{~mol} \mathrm{~L}^{-1} \mathrm{NaCl}$ and with $\mathrm{Fe}_{2} \mathrm{O}_{3} \mathrm{CBD}(\mathrm{p}<0.1)$ for 0.001 , and $1 \mathrm{~mol} \mathrm{~L}^{-1} \mathrm{NaCl}$. For the second group, composed of the 13 remaining soils from tables 1 and 2, $\log K_{a}^{\text {int }}$ values for site A could be recalculated as: $3.36 \pm 0.24$ and $-7.11 \pm 0.18,2.9 \pm 0.06$ and $-5.83 \pm$ 0.07 , and $2.53 \pm 0.11$ and $5.49 \pm 0.15$ for $0.001,0.1$, and $1 \mathrm{~mol} \mathrm{~L}^{-1} \mathrm{NaCl}$, respectively. $\log K_{a 2}^{\text {int }}$ from this group correlated negatively with gibbsite $(\mathrm{p}<0.1)$, and goethite correlated positively with and negatively with $\log K_{a 1}^{\text {int }}$ for 0.1 and $1 \mathrm{~mol} \mathrm{~L}^{-1}$. For site B, no consistent correlation was found.

Soil surface area was positively correlated and soil sand content was negatively correlated with $\log K_{a 1}^{i n t}$ (Table 5) estimated by FITEQL for both CCM and DLM $(\mathrm{p}<0.05)$. For $\log K_{a 2}^{\text {int }}$, no consistent correlation was found.

According to the chemical equilibrium considered in this study, surface speciation of soils (Figure 3), following results from Visual MINTEQ, show that from $\mathrm{pH}=1.0$ to 8.5 , where

Table 4. Average intrinsic equilibrium constants from 17 Brazilian Oxisols, using the diffuse layer model (DLM), estimated by hand calculation in Excel spreadsheets for three ionic strengths

\begin{tabular}{|c|c|c|c|c|c|c|}
\hline & \multirow{2}{*}{\multicolumn{2}{|c|}{ One site }} & \multicolumn{4}{|c|}{ Two sites } \\
\hline & & & \multicolumn{2}{|c|}{ site A } & \multicolumn{2}{|c|}{ site $B$} \\
\hline & $\log K_{a 1}^{\mathrm{int}}$ & $\log K_{a 2}^{\mathrm{int}}$ & $\log K_{a 1}^{\mathrm{int}}$ & $\log K_{a 2}^{\mathrm{int}}$ & $\log K_{a 1}^{\mathrm{int}}$ & $\log K_{a 2}^{\mathrm{int}}$ \\
\hline \multicolumn{7}{|c|}{$0.001 \mathrm{~mol} \mathrm{~L}^{-1} \mathrm{NaCl}$} \\
\hline Average & 3.28 & -7.29 & 3.92 & -6.58 & 3.97 & -6.59 \\
\hline $\mathrm{SD}^{(1)}$ & 0.43 & 0.18 & 1.13 & 1.07 & 0.71 & 0.51 \\
\hline \multicolumn{7}{|c|}{$0.1 \mathrm{~mol} \mathrm{~L}^{-1} \mathrm{NaCl}$} \\
\hline Average & 2.93 & -5.92 & 3.51 & -5.29 & 3.66 & -5.19 \\
\hline $\mathrm{SD}$ & 0.26 & 0.27 & 1.11 & 1.05 & 0.47 & 0.58 \\
\hline \multicolumn{7}{|c|}{$1 \mathrm{~mol} \mathrm{~L}^{-1} \mathrm{NaCl}$} \\
\hline Average & 2.61 & -5.59 & 3.14 & -4.94 & 3.16 & -4.86 \\
\hline SD & 0.27 & 0.35 & 1.18 & 1.07 & 0.62 & 0.64 \\
\hline
\end{tabular}

(1) SD: standard deviation.

Table 5. Average intrinsic equilibrium constants from 17 Brazilian Oxisols, using the diffuse layer model (DLM) and the constant capacitance model (CCM), estimated by FITEQL 4.0 for three ionic strengths ${ }^{(1,2)}$

\begin{tabular}{|c|c|c|c|c|}
\hline & \multicolumn{2}{|c|}{ DLM } & \multicolumn{2}{|c|}{ CCM } \\
\hline & $\log K_{a 1}^{\mathrm{int}}$ & $\log K_{a 2}^{\mathrm{int}}$ & $\log K_{a 1}^{\mathrm{int}}$ & $\log K_{a 2}^{\mathrm{int}}$ \\
\hline \multicolumn{5}{|c|}{$0.001 \mathrm{~mol} \mathrm{~L}^{-1} \mathrm{NaCl}$} \\
\hline Average & $\mathrm{NC}^{3}$ & $\mathrm{NC}^{(3)}$ & $\mathrm{NC}$ & $\mathrm{NC}$ \\
\hline $\mathrm{SD}^{(1)}$ & - & - & - & - \\
\hline \multicolumn{5}{|c|}{$0.1 \mathrm{~mol} \mathrm{~L}^{-1} \mathrm{NaCl}$} \\
\hline Average & $\mathrm{NC}$ & $\mathrm{NC}$ & 3.51 & -5.94 \\
\hline $\mathrm{SD}^{(4)}$ & - & - & 0.41 & 0.60 \\
\hline \multicolumn{5}{|c|}{$1 \mathrm{~mol} \mathrm{~L}^{-1} \mathrm{NaCl}$} \\
\hline Average & 3.45 & -5.49 & 3.58 & -5.36 \\
\hline $\mathrm{SD}^{(1)}$ & 0.38 & 0.59 & 0.52 & 0.74 \\
\hline
\end{tabular}

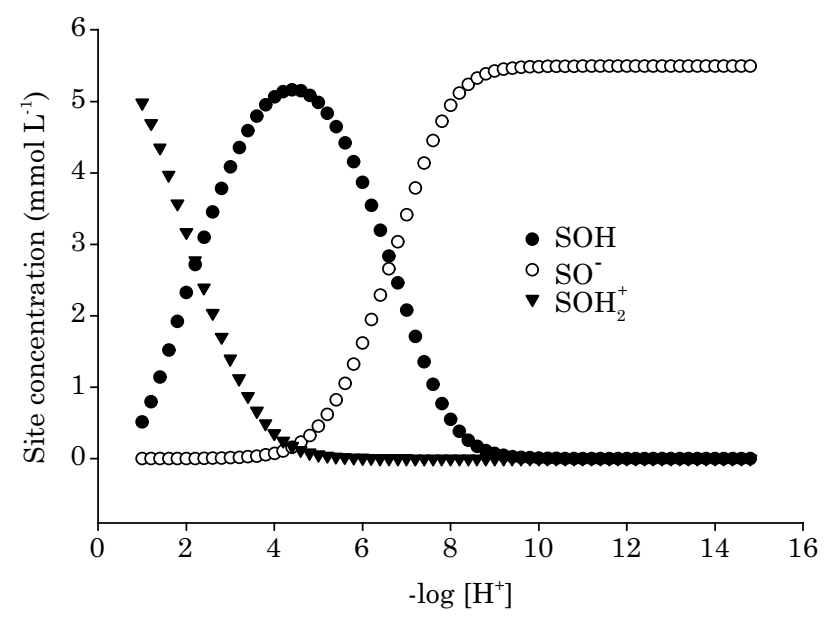

Figure 3. Output from Visual MINTEQ (Gustafsson, 2012) of surface speciation data at $0.1 \mathrm{~mol} \mathrm{~L}^{-1} \mathrm{NaCl}$ using the one site diffuse layer model (DLM) with average surface charge $\left(\mathrm{Nt}=109.9 \mathrm{mmol} \mathrm{kg}^{-1}\right)$ and intrinsic equilibrium constants estimated by hand calculation in Excel spreadsheets $\left(\log K_{a 1}^{\text {int }}=2.93\right.$; $\left.\log K_{a 2}^{i n t}=-5.92\right)$, and $200 \mathrm{~g}$ soil $\mathrm{L}^{-1}$; average surface area of $154.04 \mathrm{~m}^{2} \mathrm{~g}^{-1}$, from 17 Brazilian Oxisoils. 
$\mathrm{pH}_{\mathrm{PCZ}}=4.42\left[\mathrm{pH}_{\mathrm{PCZ}}=0.5\left(\left|p K_{a 1}^{\text {int }}+p K_{a 2}^{\text {int }}\right|\right)\right]$, the predominant species is neutral (Figure 3), and with the increase of $\mathrm{pH}$ from 4.5 to 6.5 (usually found in crop soils in Brazil), the charge increases from virtually nill to $\sim 109.9 \mathrm{mmol} \mathrm{kg}^{-1}$ as [SO-] in the soil.

\section{CONCLUSIONS}

Estimated values are ready for incorporation in geochemical speciation platforms such as Visual MINTEQ and provide a modeling system that can predict the protonation-dissociation reactions in Oxisols under changing environmental conditions.

Both values, estimated by hand calculation or optimized by FITEQL, allowed simulation of values of surface charges in Oxisols for varying $\mathrm{pH}$ values using Visual MINTEQ.

These values are more appropriate for use in surface complexation reaction modeling in Oxisols than using model parameters derived from average pure oxide materials.

\section{ACKNOWLEDGMENT}

The authors wish to acknowledge Dr. Sabine Goldberg from the University of Riverside, Riverside, CA for her helpful comments during the calculation phase of this study.

\section{REFERENCES}

Alleoni LRF, Peixoto RTD, Azevedo AC, Melo LCA. Components of surface charge in tropical soils with contrasting mineralogies. Soil Sci. 2009;174:629-38.

Carter DL, Heilman MD, Gonzalez CL. Ethylene glycol monoethyl ether for determining surface area of silicate minerals. Soil Sci. 1965;100:356-60.

Charlet L, Sposito G. Monovalent ion adsorption by an Oxisol1. Soil Sci Soc Am J. 1987;51:1155-60.

Chorover J, Sposito G. Surface-charge characteristics of kaolinitic tropical soils. Geochim Cosmochim Acta. 1995;59:875-84.

Davis JA. Application of surface complexation modeling to selected radionuclides and aquifer sediments. Menlo Park [CA]: U.S. Geological Survey; 2008.

Davis JA, Kent DB. Surface complexation modeling, in aqueous geochemistry. In: Hochella MF, White AF, editors. Mineral-water interface geochemistry. Menlo Park [CA]: Mineralogical Society of America; 1990. p.177-260.

Dobbss LB, Canellas LP, Alleoni LRF, Rezende CE, Fontes MPF, Velloso ACX. Eletroquímica de Latossolos brasileiros após a remoção da matéria orgânica humificada solúvel. R Bras Ci Solo. 2008:32:985-96.

Duquette M, Hendershot W. Soil surface charge evaluation by back-titration: I. Theory and method development. Soil Sci Soc Am J. 1993;57:1222-8.

Dzombak DA, Morel FMM. Surface complexation modeling: Hydrous ferric oxide. New York: John Wiley; 1990.

Empresa Brasileira de Pesquisa Agropecuária - Embrapa. Serviço Nacional de Levantamento e Conservação de Solos. Manual de métodos de solo. Rio de Janeiro:1979.

Goldberg S. Adsorption models incorporated into chemical equilibrium models. Chemical equilibrium and reaction models. Madison [WI]: Soil Science Society of America; 1995. p.75-95.

Goldberg, S. Modeling boron adsorption isotherms and envelopes using the constant capacitance model. Vadose Zone J. 2004;3:676-80.

Goldberg, S. Reanalysis of boron adsorption on soils and soil minerals using the constant capacitance model. Soil Sci Soc Am J. 1999;63:823-9.

Goldberg S. Sensitivity of surface complexation modeling to the surface site density parameter. J Colloid Interf Sci. 1991;145:1-9.

Goldberg S. Use of surface complexation models in soil chemical-systems. Adv Agron. 1992;47:233-329.

Goldberg S, Corwin DL, Shouse PJ, Suarez DL. Prediction of boron adsorption by field samples of diverse textures. Soil Sci Soc Am J. 2005;69:1379-88.

Goldberg S, Forster HS, Godfrey CL. Molybdenum adsorption on oxides, clay minerals, and soils. Soil Sci Soc Am J. 1996;60:425-32.

Goldberg S, Lesch SM, Suarez DL. Predicting boron adsorption by soils using soil chemical parameters in the constant capacitance model. Soil Sci Soc Am J. 2000;64:1356-63.

Goldberg S, Lesch SM, Suarez DL. Predicting molybdenum adsorption by soils using soil chemical. Parameters in the constant capacitance model. Soil Sci Soc Am J. 2002;66:1836-42.

Goldberg S, Sposito G. A chemical model of phosphate adsorption by soils: I. Reference oxide minerals. Soil Sci Soc Am J. 1984a;48:772-8.

Goldberg S, Sposito G. A chemical model of phosphate adsorption by soils: II. Noncalcareous soils. Soil Sci Soc Am J. 1984b;48:779-83.

Gustafsson JP. Visual Minteq 3.1. Stockholm: KTH, Department of Land and Water Resources Engineering; 2014.

Hayes KF, Redden G, Ela W, Leckie JO. Surface complexation models - an evaluation of model parameter-estimation using fiteql and oxide mineral titration data. J Colloid Interf Sci. 1991;142:448-69.

Herbelin A, Westall J. Fiteql 4.0: A computer program for determination of chemical equilibrium constants from experimental data. Corvalis [Oregon]: Department of Chemistry, Oregon State University; 1999.

Jonsson C. Modeling of glyphosate and metal-glyphosate speciation in solution and at solution-mineral interfaces [thesis]. Umea [Sweden]: Umea University; 2007.

Kriaa A, Hamdi N, Goncalves MA, Srasra E. Acid-base properties of tunisian glauconite in aqueous suspensions. Int J Electrochem Sci. 2009;4:535-50. 
Maichle R, Singh A. Pro-ucl 5.0. Statistical software for environmental applications for data sets with and without nondetect observations. Atlanta [GA]:USEPA; 2013.

Marchi G, Guilherme LRG, Chang AC, Curi N, Guerreiro MC. Changes in isoelectric point as affected by anion adsorption on two Brazilian oxisols. Comm Soil Sci Plant Anal. 2006;37:1357-66.

Mehra OP, Jackson ML. Iron oxide removal from soils and clays by a dithionite-citrate system buffered with sodium bicarbonate. Clays Clay Miner. 1960;7:317-27.

Miller GP. Surface complexation modeling of arsenic in natural water and sediment systems. Socorro [New Mexico]: New Mexico Institute of Mining and Technology, Department of Earth and Environmental Science; 2001.

Pierangeli MAP, Guilherme LRG, Curi N, Silva MLN, Oliveira LR, Lima JM. Teor total e capacidade máxima de adsorção de chumbo em Latossolos brasileiros. R Bras Ci Solo. 2001;25:279-88.

Schwertmann U. Differenzierung der eisenoxide des bodens durch extraktion mit ammoniumoxalat-lösung. Z Pflanzenernähr Düng Bodenkd. 1964;105:194-202.
Silva MLN, Curi N, Marques JJGSM, Guilherme LRG, Lima JM. Ponto de efeito salino nulo e suas relações com propriedades mineralógicas e químicas de Latossolos brasileiros. Pesq Agropec Bras. 1996;31:663-71.

Stumm W, Kummert, R, Sigg, L. A ligand exchange model for the adsorption of inorganic and organic ligands at hydrous oxide interfaces. Croat Chem Acta. 1980;53:291-312.

Stumm W, Morgan JJ. Aquatic chemistry: chemical equilibria and rates in natural waters. New York: John Wiley \& Sons; 1996.

Sukhno I, Buzko V. Ionic strength correction for stability constants using Specific Interaction Theory (SIT) Krasnodar [Russia]: IUPAC; Kuban State University; 2004.

Tognon AA, Demattê JLI, Demattê JAM. Teor e distribuição da matéria orgânica em Latossolos das regiões da floresta amazônica e dos Cerrados do Brasil Central. Sci Agric. 1998;55:343-54.

Vettori L. Métodos de análise de solo. Rio de Janeiro: Ministerio da Agricultura-EPFS; 1969.

Westall J, Hohl H. A comparison of electrostatic models for the oxide/solution interface. Adv Colloid Interf Sci. 1980;12:265-94. 